\title{
Resisting the Current "Refugee" Discourse: Between Victimisation and Reclaiming Agency
}

\author{
Sabine BaUER-AMIN, Vienna
}

\section{Content}

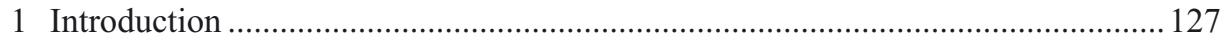

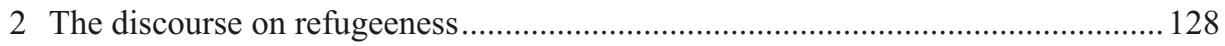

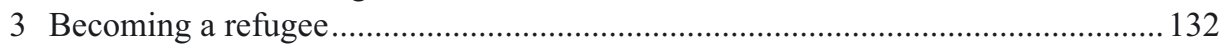

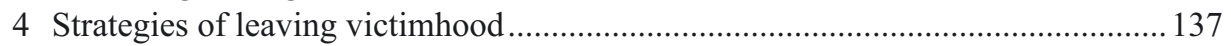

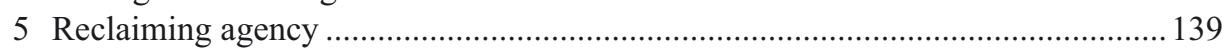

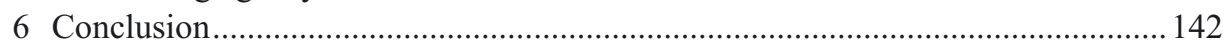

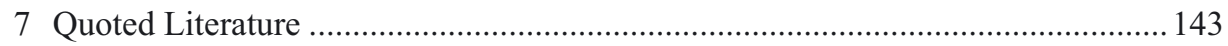

\section{Introduction}

When entering the term "refugee" into a search engine, the pictures that show up might be of children or women in unbearably poor conditions. Depicted as not being able to end their misery themselves, these pictures are often used by agencies to mobilise support from those in situations that are more privileged. Although for a huge number of people such conditions are a daily reality, they do however not mirror the situation of everyone and contradict in many ways the original idea of political refugees of the 1951 Refugee Convention. Instead, they create an alternative discourse of "refugeeness" as victims of not just violence, but of economic vulnerability (inter alia) with no other choice than submitting into humanitarian aid. While such pictures of war and poverty merge into a common knowledge over what it might be like to be a refugee, it has to be noted, that such assumptions are representational constructions. These are based on 
mechanisms of victimisation that deprive refugees of agency in order to create them as "suffering objects", embedded in humanitarian discourses. Consequently, in the current discourse the people depicted are often reduced to their bare refugeeness under the negligence of all other possible points of identification. This has not always been the case, but was rather a development of the past forty years. Since the 1980s there had been a "tendency of depicting displaced persons simply as mute, helpless victims rather than specific persons" (ELIE 2014, p. 30), those who did not let others mute them, were often simply left out of the discourse.

However, there are people affected by forced migration who do not agree to be reduced to their naked "refugeeness" and rather claim to be more than just victims of their situation. Very much aware of the tensions between being forced to leave their homes and reclaiming agency and self-determination, they negotiate their positions in their new places of residency. While experiences of war and flight are important and undeniably painful luggage on their journey onwards, it is not just this that makes up their personhood. Based on a comparative analysis of four interviews from people who left Syria, this chapter will shed a light on how they cope with the narratives of victimhood and reclaim their agency. As highly skilled refugees, who themselves had representative positions or high-class statuses before, they do not want to be at the receiving end of societal dynamics, but ask to be considered equal to their (often soon to be) co-citizens in Austria. They want to be humans to interact with, and not victims to be helped. It has to be noted however, that these examples tend to be people who are from higher social classes. They are artists, activists or have a background in politics and are not a representative majority, but still a large number of people, who are often ignored in discourses about refugees, as they resist fulfilling the predicaments of victimhood. What is however behind the label "refugee"? For decades, the question was about who should be labelled a refugee and not "just" a migrant. Now, I would like to raise the question about people who do not want to be only "refugees"? How can they step out of the "refugee-trap"?

\section{The discourse on refugeeness}

Since the 1980s public discourse about refugees and refugeeness mainly depicted refugees as victims. Hence, "myths of differences" were created for several - quite often very strategic - reasons based on often good intentions (JOHNSON 2011: 1023). Hence, by writing out the notion of "class" and presenting refugees homogenously as desperately poor and dependent on the intervention of others, "rescue" narratives were a way of mobilising public support. Based on these differences towards the well-off receiving and donating populations the discourse allowed supralocal organisations and 
NGOs to mobilise funds, which were often needed to help the NGOs themselves to survive. Moreover, policymakers could justify interventions and programmes based on humanitarianism (JoHNSON 2011, p. 1016).

This happened mainly by constructing a picture similar to what JOHNSON describes as:

\begin{abstract}
"Starving, barefoot children on the backs of exhausted mothers. Huddled bodies crammed into a boat in dangerous waters. Women mourning the loss of husbands, sons and fathers. $[\ldots][M]$ asses of humanity, nameless women and children fleeing violent conflict and living in destitution, the victims of tragedy searching for a place where they can rebuild shattered lives." (2011, p. 1050)
\end{abstract}

Over the past decades, such pictures became indexical representations of refugeeness. According to BLEIKER, it is through representations that meanings are introduced to the public (BLEIKER 2001, p. 515). Hence, the dynamics of representation, visualised and legitimised through constructions as the above, shape meanings in the wider social world. However, they are based on acts of power. "They tell us how to interpret our world, and shape our imaginations" (JoHNSON 2011, p. 1017). As women and children constitute in Western imaginary especially vulnerable and powerless kinds of humans according to RAJARAM, they are often chosen to represent refugee crises (RAJARAM 2002, p. 252). In addition, the hierarchy of empathy then includes also fathers, elderly people and minorities. These groups seemed to be aligned along a continuum of who looks less like a "dangerous alien" in Liisa MALKKI's words (MALKKI 1995, p. 11). What they have in common however, is their often unbearable hopelessness and poverty. Hence they constitute the poorest of the poor, living with nothing left in a refugee camp somewhere in the (mostly sub-Saharan African) Global South, in an already poverty affected receiving state (see e.g. Images of Exile by UNHCR, 1991). Apart from this gerontation and genderisation, the mechanisms for the construction of refugee representations in the last decades also included a racialisation. Most of those pictured represent the Global South; often sub-Saharan Africans or Asians (JoHnson 2011, p. 1015). (Middle Easterners however, were often presented in very different discourses, especially after 9/11 and hence fell into different categories of perception). Moreover, notions of class where overwritten. Usually it was not the people from better-off sections of the refugee groups that made it onto the materials offered by humanitarian agencies, but rather those "desperately poor" and unable to survive without the help of those depicting them and their donors (JoHNSON 2011, p. 1030).

These quite often very strategic mechanisms helped to construct a particular social knowledge about refugees, based on processes of dominance and resistance, where power was clearly ascribed to those on the donating and "rescuing" side, while those on the receiving end were disempowered (JoHNSON 2011, p. 1070). Hence, within the discourse 
that created this social knowledge, refugees were not individuals, but "masses" of people (Johnson 2011, pp.1024, 1026) without "personal histories, stories and reasons for exile" (Johnson 2011, p. 1026). They were no longer critical figures or dissidents of their respective regimes, but voiceless victims without any political agency and fully dependant on international interventions and the receiving states (JoHnson 2011, p. 1016). While this discourse helps policymakers to manage the fear of instability posed by the presence of the new "other" among their resident citizens, it also controls the political agency of those labelled "refugees" (JoHnson 2011, p.1027). Finally, it justifies the support for politics of humanitarianism and at the same time locates the "problem" somewhere in the Global South and not within the receiving country (Johnson 2011, p. 1027), as was powerfully shown in the case of Alan Kurdi, the Syrian toddler who drowned on the Turkish coast. Just days after the picture of his dead body was spread through social media, Germany, for instance, changed their border policies as a result of huge public pressure and large critics on how the presence of large numbers of Syrian refugees in Turkey had been handled so far.

To go in further detail: This discursive practice, which is often based on valid points and best intentions, creates an archetype of someone who is "harmless and in need" (RAJARAm 2002, p. 247). This stripping off the subject of political agency, time, place and history (MALKKI 1995, pp. 11-12) is especially significant in a context where most refugees nowadays come from Muslim majority countries, because it contradicts the growing fear of suspected radical Islamism within these groups. Through such practices, however, they create a nameless suffering object, but very often not a faceless one. As the refugee "lost" the right to a personal story and concerns of privacy, often photographers do not care about showing their faces without permission. That became for example apparent in the prize-winning image of the four ladies and the infant on Lesvos (by Lefteris PARTSALIS 2016). Three of them were elderly residents of the island and were often presented with their full names, while the forth one remained a nameless Syrian woman, the mother of the infant. While the three ladies were celebrated for their efforts in helping refugees even nominated for the Nobel Peace Prize, the Syrian woman, whose face is clearly visible, stays anonymous and her story and personality reduced to her being a refugee mother from Syria (TAGARIS 2016).

These representations carry the danger of essentialising people to their naked refugeeness and dehumanising them as suffering objects without their own will or rights other than those afforded to them as refugees, as shown in the example. Thus, refugees become an abstract figure without a story whose personal experience becomes devalued (JoHNSON 2011, p. 1031). Stripped of any personality, only the basic archetype of a "refugee" remains, homogenising a large and vast number of people of all different kinds of walks of life, classes, gender, religions, reasons to leave their countries and wishes to return or not. If differentiations are made at all, people are grouped according 
to nationalities, which is especially dangerous in places shaken by civil wars, like Syria and excludes minorities, like Kurds. Hence, these processes override the complexities that this category entails (ZETTER 2007, p. 174).

The named mechanisms create an emblem or attach a certain refugee label to people. ZETTER defines this process as "examining who you are in relation to others" (ZETTER 2007, p. 173). However, these labels are never neutral (ZETTER 2007, p. 186). From the perspective of those actively claiming them, being labelled a refugee can help gain public visibility for one's situation, which is especially important for social movements and oppositional groups or minorities. Moreover, this label and the connotation of helplessness evokes feelings of social responsibility and can help to promote ethnic branding. On the other hand, it might be often a strategic decision to claim refugee-status under circumstances of ongoing persecution, as it enables access to certain rights granted by the Geneva Convention, that minority status does not.

The price however, is not seldom quite high; being a refugee might include being deprived of personal rights, dreams, stories, fears or worries. Often people face problems when they can or do not want to fulfil the expectations raised by the public social knowledge about refugees by the receiving residents. Moreover, the mismatch also problematises relations with authorities and policymakers as their "not-sopoorness" or exerted agency might undermine humanitarian justifications of the refugee status (BAKEWELL 2010, p. 1690). However, ironically, these rather middle-class and well educated refugees then exactly fulfil the original idea of "the refugee", that was displayed in 1951 at the United Nations Convention relating to the Status of Refugees, concerning individuals who made conscious choices to flee the repressive Soviet regime to live in 'democracy' and 'freedom' (JoHNSON 2011, p. 1015).

This discourse of victimisation, dominant within UNHCR programmes and policies, deprives people of political agency. JOHNSON defines it as "the ability to have an impact both upon one's own life and upon the lives of others" (JoHnson 2011, p. 1028). These abilities are hence usually located within the notion of citizenship. Hence, NyERs explains that a citizenship entails a political identity that entitles someone to claim equal rights, liberty, self-determination, individualism or agency (NYERS 2004, p. 203). By denying people these rights, they are turned into non-citizens (JoHnson 2011, p. 1028). Johnson bases this on the fact that granting these rights to refugees would disturb the relation between political agency and citizenship, which are "the founding premise and structure of the nation state and popular sovereignty upon which the international system rests" (JoHnson 2011, p. 1028). Hence, SoguK reasons convincingly that the aim of humanitarian intervention is not "human beings as victims of a state gone aberrant. Rather, the object of intervention [...] is citizens gone aberrant to become refugees" (SoGuK 1999, p. 177). Thus, political involvement is often not wished for by refugees, neither its impacts in their "countries of origin", nor in their new places of residency, 
as such activities are often seen as an uncontrollable political threat (JoHnson 2011, p. 1028).

Therefore, refugees are sometimes quite willingly depicted as voiceless victims without self-determination, as in the 1988 "Year in review" that begins with the words: "Refugees need a permanent home. But, as victims of persecution and war, they have minimal control over their destinies [...] refugees are the flotsam of power struggles" (WINTER 1988, p. 2). However, as victims of persecution, violence or civil wars, they are primarily political. By denying citizenship and a political agency people lose their ability to act politically (JoHNSON 2011, p. 1029). Hence, the topic of the levels of determination and voluntarism becomes a critical point in the debate, since the denial of agency or choice is often the basis for debating the concept of forced migration, in contrast to other forms of migration that are often thought of more in terms possibility of choice (BAKEwELL 2010, p. 1689). Although forced migration had been studied with growing interest and significance, matters of individual decision-making were often simply ignored or downplayed (De Jong and FawCETT 1981, p. 45). Hence, on the one hand, underlining the forced in forced migration, and on the other side claiming agency and self-determination creates a tension that goes against the notion of "refugeeness" promoted over the last 40 years. On the other hand, refugees themselves are often very much aware of this tension, as well as the discourse. The pictures of poverty afflicted and helpless womenandchildren (Cynthia ENLOÉ in JOHNSON 2011, p. 1032) were circulating not only through Europe, but also through many countries where the refugees themselves departed from or crossed through. What if the people do not want to represent this image of voiceless victimhood? What if they prefer to be seen and heard, strife to regain political impact and want to be at the giving rather than at the receiving end of the power structures in their new places? How do they reclaim agency and empower themselves again? How do they navigate through the tensions that the refugee or forced migrant label brings with in terms of loss of agency and reclaiming it through being heard as people with voice, agencies, stories, hopes and fears?

\section{Becoming a refugee}

One of the participants in this study was a 37 year-old man from Darbasiyah in the Syrian Kurdish North and a well-known musician. He had often come to Europe as an artist performing Kurdish music in the field of world music, a musical genre trending over the last couple of years. "I was travelling intensively to Europe. [...] As a musician", he explains (Sy6: 47-50). He recalls several incidents when the Prince of Denmark or the Staatsoper in Berlin invited him. For him it was always easy to travel abroad as a renowned artist from Syria. He had worked already in Damascus as a bouzouk player, singer and composer and held a position as tutor at the Faculty of Music Education in 
Homs. Together with his band he had toured through the region and Europe since 2007 and even won awards outside of the Arab world.

However, his situation in the country had never been an easy one. He describes many incidences, where, as a Kurdish musician, he was under scrutiny by the state. "I mean, to be Kurdish in Syria it is, erm.., it was not so easy to handle it, because especially as artist, because you are belonging to a culture which is forbidden" (Sy6: 474-475). He hints at the strict surveillance of ethnic minority of Kurds in the state. Later he makes it even clearer, when he says: "Because when I move in Damascus, I was not treated as a Syrian, I was treated as a Kurd.”'(Sy6: 368-369).

For him and his family, the situation changed when the war in Syria broke out. He tried to be involved in projects and retain his artist visa for Europe that allowed him to continue travelling. He spent most of the war days out of the country. At the same time, his wife had left Damascus, where they had lived with their small child and stayed with family in the Kurdish North. However, he wanted to bring his wife and child to a place with more security. Hence, he had to find a possibility to spare them the dangerous sea route. For that reason he had to turn down his artist visa and apply for asylum while in Europe (Sy6: 26). This was the only possibility for him to bring his small family to Europe. With that, also his rights and claims to cosmopolitanism altered; the public perception of the artist had changed. While before, he was invited for his performance of Kurdish music, among other reasons, he was now one of many Syrian refugees in Europe. Although he explains, that he keeps on being invited to Germany and Switzerland to perform, he cannot do so anymore everywhere. Although he foremost still sees himself as an artist, his new legal status for example does not allow him to leave to Syria for any reason.

When he describes himself in the interview, it is important for him to underline, that he did not come directly from Syria, but from England, where he wanted to do a postgraduate course in ethnomusicology (Syr6: 22). On his homepage, he never refers to himself as a refugee, but rather underlines his self-determination by explaining that he is living with his family in Austria because of the situation in Syria. He moreover makes it clear that he willingly and very consciously exchanged his artist visa for that of an asylum seeker for the sake of his family (Syr6: 26, 17). On the other hand, he also recalls his lack of choice (Sy6: 251-257). Hence, he navigates the tension of claiming on the one side to be a victim of forced migration and on the other hand to have freely decided to be one. Hence, what becomes more obvious is that he underlines the context in which he changed to be an asylum seeker and the awareness with which he did this.

Similarly, his wife became a refugee by leaving Syria and following her husband to Austria. After finishing her studies in sociology in Damascus, she worked for many years as a social worker in a girls school, where she tried to fight the danger of women not taking their education seriously enough (Sy11: 34-36; 65-69). Dedicating her career to strengthening the role of women in society, she tried to raise awareness of this issue 
during her time in Syria (Sy11: 78-81, 117-121). However, the situation in the country changed her ambitions. After her husband could no longer give concerts (Sy11: 122125 ) and she could not send her son to kindergarten for security reasons (Sy11: 132133) it was clear, that she had to leave her old life behind. She explains that they had thought their plan through of how to leave the country and reach Europe (Sy11: 142144). However, after her husband left, it took them nine months to reunite in Vienna again (Sy11: 150-152). During that time, she had to leave her house several times. First, she left from Damascus to her parents' house in the Kurdish North and then to her husband's parents in a neighbouring village, because of the approaching militant Islamic State group (Sy11: 165-173). The times as a then internally displaced person in the village were hard for her, as she describes the lack of water and electricity supply (Sy11: 193-194).

When she pictures her first months as a new refugee in Austria, she admits, that it was complicated. She refers to a psychological pressure that she experienced knowing that she was forced to leave a place behind that she did not want to leave and the worries she had about her family who remain in the war zone (Sy11: 239-243). Apart from this, she describes too, how difficult it was to start her life from the scratch without knowing the language. It did not matter how well educated she was or how much effort she had invested before in pursuing her career. She then adds that furthermore she did not know anyone, had no friends, but many financial worries (Sy11: 239-249). Hence, she refers to the painful experience how all her personality and her previous life no longer counted; in the moment she became a refugee she was back at zero, a tabula rasa. The young mother explains exactly the described in-temporality of refugeeness and the state of helplessness into which she was forced. Neither her story, nor her education counted. What was even worse for her was that the psychological pressure, her worries about her family and her difficulties also did not count, as she was a mere abstract figure.

Another participant in the study was s a female activist in her fifties, who was actually working as a maths teacher in the city of Der'a, from where the revolution started. As her ex-husband had been stationed in Austria before, she used to travel to visit him and see the countries around on a regular basis. As a political activist in Syria, she was used to being observed. "The walls have ears", she explains (Sy4: 9, 10). Having been an opponent of the Assad family for a long period, she had been waiting for something to change in Syria as well. Motivated by the so-called "Arab Spring" in other countries, she hoped that the revolution would make a change and started to be active in different civil movement groups (Sy4: 29-31, 110). "Now it's the time to, to serve, serve the country. [...] We feel like something holy, something very pure. And it's nothing about the religion that time", she describes her motivation to join these movements (Sy4: 101-102; 104-105). The lady then started to collect video footage of security forces misusing their powers against civilians and sent it to media abroad (Sy4: 114117). However, the price she paid for her activities was that a year later she was thrown 
in prison for seven months (Sy4: 129-130). Shortly afterwards, her younger brother was also imprisoned, but other than her he never returned (Sy4: 130, 131, 151-154). When it was clear, that he had been killed, she made the decision to flee. When she received an invitation to a conference in Turkey, she left Syria. She stayed in Turkey to attend the conference and then worked there with what she called "the interim government" (Sy4: 156). After facing some problems with the party there and without regular income, she felt endangered in Turkey. "One of my friends they killed him, in Turkey, in Gaziantep where I used to live. From ISIS, this time, because, Turkey is full of people belonging to the regime and to the ISIS and for me, I am of course enemy of both" (Sy4: 163-165). Meanwhile also her private situation had changed, since her mother, her daughters and grandson had joined her in Turkey. Finally, she did not see any other future for her family other than leaving on a boat for Europe. The former activist from the opposition movement was hence turned into a refugee, when she arrived in a huge group of 42 people in Europe. She then describes in detail their journey through Europe over Greece, with a fake passport over France, Netherlands, Germany and finally Austria (Sy4: 317332, 369-374). The former math teacher describes how she willingly chose Austria to stay with one of her daughters, who had been living in the country already for years and underlines, that the daughter "never even took money from the Sozial[amt] (social welfare). She worked, always she worked and now she even admitted for nationality" (Sy4: 425-426). However, the politician talks also about her fears and how the experience has changed her life. When she talks about Syria, she laments: "He [Assad] damages everything, he damaged not only the houses, the people, the victories, the kids, our, our feeling. [...] I have a lot of pain inside me but I tried to avoid this feeling and to forget about it. But still, do you think, that erm, really we can feel happy?" (Sy4: 499-503). She then goes on and speaks about the family celebrations from which her brother is absent now and what the knowledge of him being tortured to death means to the family (Sy4: 511-523).

Moreover, she addresses her refugeeness as such. She explains how a Danish journalist had accompanied them on their flight. "So he talks about all of us and he has photos" (Sy4: 848) she explains without commenting on how it felt to be reduced to be "just a refugee". What however was more painful for her was when she encountered other groups of immigrants in Austria who distanced themselves from being a refugee. "As if we have, it's a shameful thing, or guilty because we are refugees?" (Sy4: 727728). Hence, the political activist underlines, how the connotations of the refugee label brought her into a situation of powerlessness, especially by others who themselves where striving against downward social mobility and their place in society. "[T]he, [...] non-Austrian and they came from long time of course they feel now they are like higher position than the refugees, even if they are Syrian" (Sy4: 722-723). The activist points at sensitivities of people whom themselves or their parental generations once moved to Austria and who often oppose the reception of new refugees, whom they see as a danger to the status they had been establishing over years. 
The fourth person is a 34 year-old man from al-Malikiya at the northwestern triple border between Syria, Iraq and Turkey. There he was working as a teacher of Arabic literature in Syria. Not only did he work for a public school, but also founded a private school together with some of his friends (Sy14: 30-38). He wrote his own Arabic-school books, that he also brought with him to Austria (Sy14: 44-45). However, he faced problems when the situation in his area changed in 2012, as he is Kurdish. He explains that the Arab Christians in the mixed area mostly supported the president, whilst the Kurds opposed him. Moreover, $15 \mathrm{~km}$ from his hometown, the Salafist leaning Al-Nusra front positioned themselves (Sy14: 102-106). When the Christians stopped coming to the public school, he volunteered to teach them in their local church for free. (He taught in a Syrian Orthodox and in a Protestant church) (Sy14: 119-123).

When Al-Assad's bomb attacks destroyed the neighbourhood where his family lived, most of his family fled to nearby Iraq (Sy14: 189-191, 198). He himself decided to stay and keep on volunteering as a teacher. However, he received a warning by a former student, who was now involved in the al-Nusra front and his father that they were about to kill him or his family for teaching in a church as a Muslim (Sy14: 168-176). Within 24 hours, he then prepared his assets and left with his wife and little child. The young teacher had no chance to take documents or certificates with him, traces of his former life in Syria, and rather focused on selling his belongings to be able to afford the expensive journey (Sy14: 140, 141; 182-186).

Hence, with the help of his brother, who was already living in Austria, he arrived as a refugee to Traiskirchen, a refugee camp close to Vienna, and was then in his own words "transported" to another Austrian town, Vöcklabruck (Sy14: 247-249). He then goes into a long description of how he felt as a disempowered and multiply displaced refugee played out in the hands of the Austrian authorities, where other people decided over his destiny. He explains for example how his responsible official treated him, when he asked for German classes: "Okay, you speak a little bit of German. You don't get any German classes. There are people who need A1 [beginner's classes] and you speak well, that means you are B1 [intermediary] and you don't need it. [...] I don't give you a German class" (Sy14: 276-279, translation by the author). And when he tried to take destiny in his own hands and find an alternative way to study the language in another institution, the official told him: "You belong to us, you have to stay with us" (Sy14: 289-290, translation by the author). The young men thus describes his initial experience as being a refugee as being a driftwood, at the mercy of the mood of local authorities, completely stripped of any self-determination and as if he was no longer a full person, but a state ward without rights and voice.

All the four of the people described above detailed how their privileged position as well-educated citizens in Syria and their own and although different, yet similar stories and decisions to leave the war zone turned them into refugees as suffering and helpless objects, not more and not less. Notable however is, that while the decision to leave 
Syria is described by all the three of them as an active choice. Their memories of their trajectories to Europe contain tales of agency, pragmatism and decision-making. While the feeling of "hav[ing] minimal control over their destinies" and being a "flotsam of power struggles" as described in the 1988 Yearbook on Refugees (WINTER 1988, p. 2) only set in after their arrival in Austria.

\section{Strategies of leaving victimhood}

In the various fields that the four case studies were active in before their flight, their success was often based on networking skills. The more one could make acquaintances and connections, the better. This kind of relational network of favours is called wasta in Arabic and is often mistranslated into corruption or nepotism. Although in its extreme forms wasta can result into these through the abuse of important connections, it means often simply indirect social relations within networks that help to facilitate things through intermediaries. For many years, this was an important asset of the teacher and the activist to save their own careers and in the musician's case also able to provide him with a livelihood and the necessary connections abroad. In times of crisis, these networking skills can be extremely valuable, as they immediately provide a sense of belonging, help and support, if needed.

The young Arabic teacher for example did not give up as a disempowered noncitizen in Austria and rather mobilised his old networks to facilitate his arrival, such as members of the church in which he had volunteered, who are now based in Germany. The priest wrote a letter explaining how he worked for free in the church in Syria, which helped him later in his asylum application, (Sy14: 127-138) as it turned out to be one of the few available papers describing his former life in Syria. He explains that he is still in contact with the members of the church, who are now mostly themselves refugees. He then describes how he was not satisfied with the services he was offered in Austria in terms of language training. Based on his experience of disempowerment with the local authorities, he then started to teach himself German through watching YouTube videos about the language (Sy14: 257-259). He soon went away from just depending on help from the authorities and tried to enlarge his network himself. He soon made friends with an Austrian neighbour, who helped him to look for alternative institutions (Sy14: 279281), where he continued to look for job opportunities and sent emails until he finally received an answer (Sy14: 309-311). First, the former teacher agreed to volunteer, as he had already done in Syria for the Red Cross (Sy14: 317). Because he had already developed a high level of German due to his own efforts, he then worked as a translator for Syrians and finally was offered a fixed position (Sy14: 319-351). He started to work for the Red Cross and now manages three refugee accommodations (Sy14: 379). 
Moreover, he used his own experience as first a language teacher and second someone who did not receive much support by local authorities in learning German and started to teach the language to other Arabs in his free time (Sy14: 445-447). He himself tried to regain self-esteem and personhood by navigating through his own experience using his settled and newly acquired skills. In this way, he could distinguish himself from others and turned from a helpless asylum seeker into an advisor for charity organisations dealing with refugees.

The opposition politician also used her skills and experience to navigate her newly ascribed identity as a refugee in Austria. Like many others she first tried to access German classes and find a work (Sy4: 431-434). "I feel that I can work. I don't want to sit with nothing, to feel that you are [living from] benefits, you are doing something. This is, even the money it will taste much tasty and different than this money that you gain it by your work." (Sy4: 439-441). What however, distinguished her, was her experience in political work. Therefore, she joined a political group of Syrians in Austria, with whom she meets regularly on Sundays in public spaces to make their case heard (Sy4: 653-657). On the other hand, she did not strip herself of her "refugeeness", but rather she decided to make it public. She started to give interviews about her situation and the situation in Syria (Sy4: 730-734). Her somehow "strategic essentialism" helped her to navigate between disempowerment and reclaiming agency, between victimhood and personhood. By underlining and actively participating in the public representation of her new role, she managed to bridge the divide between the two poles.

Not much different was the situation for the young social worker, who could also refer back to her education and implement it in Austria. She explains that after studying the language, she was at first dependant on the help of others (Sy11: 289-296). However, as most of her and her husband's initial contacts were musicians and fluent in English, she could from the beginning communicate freely within this community (Sy11: 374378). Her husband very soon started to work as a musician again (Sy6: 55), giving concerts and recording albums.

The musician describes how his music helped him to establish contacts with people immediately. "II]f you are not connected with people, you'll never be connected to the place”, he warns. He explains, that he felt arriving in Austria was easy, as the artist community in Vienna would welcome other artists from abroad. "[...] always in music, am, like, when you have something special, it's appreciated, because it's new thing." Within a very short time, he managed to rebuild a network and reactivate those already existing links and established his name in the Austrian cultural scene. He explains how this helped him and his family to be respected: "Because we have respect, we have job, we have our income, we travel from here very easy, nobody bother us, we don t bother anybody" (Sy6: 385-387). However, he does sometimes feels troubled, when he is seen 
as just one of many "Syrians" who came to Austria, since as a Kurd in Syria he was never treated as equal to Arabs. "I don't want to show up my identities, but the identities they are showing up by themselves" (Sy6: 497-499). He is floating between the different ascriptions of what he calls "identities", between being a Muslim, a Syrian, a Kurd, a refugee and a musician (Sy6: 596-601).

\section{Reclaiming agency}

The term agency is closely linked to performance as it underlines the individual's capacity to engage actively with their social and cultural context. Contrasted against deterministic interpretations of behaviour, in Western thought it is linked to the philosophers of the enlightenment, namely Descartes ("Cogito, ergo sum") and Kant. Understood as an opposition to naturalistic determinism, agency highlights the human capacity to make choices. In this philosophical tradition, it is linked to the idea of a free will. However, in other traditions the question of agency is not how a person reaches a decision, as this could also be seen as a result of the forces within a social system and not 'personal choice'.

The term had been debated and emphasised in anthropology in the recent years. The result was that underlying Western philosophical assumptions were questioned and anthropologists were reminded to pay greater attention to how certain ethnographic contexts shape and reshape the ideas about agency. This theoretical rethinking was especially inspired by anthropologists working on religion. Saba Mahmood for example describes in her ethnography on Muslim women's movements in Egypt the parallel existence of different kinds of moral agencies (2005). She criticises how the concept of agency, especially in subaltern and feminist studies, was identified with Western values such as freedom, autonomy or the overthrow of social norms. Mahmood hints on the Western assumption of Islamic patriarchy denying space for female agency. She thus suggests an alternative way of thinking about the concept above the notion of resistance, which she understands as a Western meta-narrative of a humanist paradigm of the free will and modernity. Therefore, she argues that instead of trying to analyse contexts according to Western assumptions, anthropologists need to incorporate the demands of the context, such as responsibility, effectivity or modes of being, as in her own research context as driving forces, rather than simply the exertion of the context-free free will (see Mahmood 2005).

Agency therefore has to be understood in its multiple contexts that each of the four people refer to. For the musician, being treated with more "dignity" than he was under the regime in Syria is what he explained to have gained from his seeking refuge (Sy6: 71-72). "You know, there is like, like, this is your dignity, you didn't kiss hands to live" (Sy6: 90-91). What is however important for him, is that he needs self-determination 
and respect as an equal human, in order to be able to feel like a full member of Austrian society, in which he feels required to integrate:

\begin{abstract}
"And which means, erm, always the, the Europe, this is big problem, in my opinion when they talk, thinking about integration, they think that we are here and people are here and we should to bring them up to be integrated, but it's also, it's respect, I cannot, I cannot stand up to you and say hello, you should be like me" (Sy6: 196-199).
\end{abstract}

He asks to not be treated as a child who needs to be socialised into the new environment, but to be seen as a full personality, shaped by former experience, traditions, and expectations. "And it is not about that you should change your tradition in your country, no. But it's also to understand what's the tradition of those people?" (Sy6: 201203). He then talks about the non-citizenship of refugees and their liminal status, before regaining citizenship in their new country. "Those people [the refugees] are here and if they [the Austrians] want and don't want this [nevertheless] is the, the Austrian citizen, the future of Austrian [state], [the refugees will became] a lot of Austrian citizenship in future. Any of this refugee, he is now here, he get his status" (Sy6: 206-208). He hence explains how new feelings of belonging to a place might come in time and not through just learning a certain habitus (Sy6: 227-230). Against the discourse of disempowerment and unequal power hierarchies, he explains, that only accepting the humanity in the other, leads to successful integration (Sy6: 337-338).

Also connected to a status of refugeeness is the denial of temporality and the closure within a timeless status. Reclaiming agency is connected to reclaiming the right to forge one's future and re-enter equal temporality. The musician therefore describes "I cannot spend my life in nostalgic stuff to why I'm not in my country. I'm not in my country and this was not my decision, but okay what I can do?" (Sy6: 447-449). In a later interview on TEDx he says, that the reason why he integrated so well into society was, that he met the right people, who did not treat him like a refugee. He then continues "I decided to not be a victim, I decided to be proactive and act differently." He tried to navigate through both, being a refugee - someone who had to face loss and has to develop a new sense of belonging - but on the other hand retaining his voice as a musician.

Similarly, the political activist is thinking about the future. On the one hand, she thinks about the future of Syria and hopes for a final success of the revolution (Sy4: 206-212). On the other hand, because all of her family are now spread over Europe as refugees, there is no reason for her to go back (Sy4: 268-269). In narrating her journey, she emphasises her free choice in coming to Austria. "I came the opposite way [of the route], I know, all the people [phone ringing] they want to run away from Austria. [...] But if I have to choose, if I can choose, I will choose Austria" (Sy4: 373-381). She explains that her new place of residence was not due to the mechanisms of international conventions, but out of her free deliberation to live with her daughter (Sy4: 403-405). 
She very soon managed to regain agency by being active within the political Syrian group in Austria that gathers at one of the central places of the city, Stephansplatz to make their case heard.

“... this type of things to remind people about our revolution and what's going on with the picture of the people, the kids, the, the victim of the chemical weapons. Imagine that he used all the weapons, even the chemical and still the world is silence. Still the world wants more evidence" (Sy4: 465-468).

She has hence declared herself a speaker for the unseen and unheard left back in the country and started to gather donations to send to projects back in Syria (Sy4: 480-481). She never wanted to identify with those receiving donations, not even at the beginning. "Okay, I came with, like first, I, I told you that I refused to take clothes or things from the organisation. Erm, I don't know, maybe I feel shy." (Sy4: 668-670). Finally, she actively positioned herself on the helping side rather than on the receiving end by volunteering at the nexus points of arriving refugees in 2015 at the Viennese train station and at the Hungarian border as a translator (Sy4: 537-545). This way, she actively left the discourse of victimisation, by helping the victims themselves.

Similarly, the former Arabic teacher used his refugee status to reclaim agency within the changed setting of Austrian policies in 2015, when more and more refugees arrived and suddenly there was a demand for Arabic speakers, who could understand the background of those fleeing warzones. He explains how it was his own decision to stay in Austria, once he reached the country and not travel further to Germany (Sy14: 225-228). He reclaimed agency, by taking responsibility for his family in Iraq, who he supports with his income (Sy14: 359-360). Not only for those did he take responsibility, but also for those refugees newly arriving in his new country, where he can help them with his own knowledge and experience of arriving in the society (Sy14: 427-434). He even explains "I have a lot of responsibility" (Sy14: 461, translation by the author). Now, under his custody are not just other Syrians, but people from Iraq, Afghanistan and other places (Sy14: 482). As a translator at the Austrian border he became a representative of Austria and proudly recounts how he received the refugees with the words "Welcome to Austria" (Sy14: 615).

However, he also claims, that he is often caught up in his thoughts about his old home, his old job, his friends and family and the way they lived. He explains that he needs to get out of this timeless loop of memories, in order to move on. "I am here since two years and I was a refugee, and even though I am manager - I manage three houses and with me are many co-workers, Austrians" (Sy14: 674-676), explains the young man his personal story of reclaiming agency and arriving in his new society as a full member. 
Likewise, the young social worker soon managed to get employment in the expanding service sector catering the refugees in Austria. She is employed by a UNHCR resettlement programme (Sy11: 551-555). There she sees herself as a mediator between the new refugees and the Austrians (Sy11: 572), a position that mirrors probably her own self-understanding. When asked how she reached that status in such a short time, she explains that it is based on her own will and the wish to do something meaningful (Sy11:285, 298). Later she explains that the success also depends on the character of the person, the self-esteem and the level of education (Sy11: 353-356).

\section{Conclusion}

The young social worker clearly describes the pre-conditions to successfully leaving a narrative of victimhood. Not just self-confidence and the will to do so, is necessary, but a certain social background. All four of the people mentioned in this article have a university education and come from influential families. Hence, they all had a certain status before they were turned into refugees (or decided to, as some would rephrase it). This might make them different from those people in the pictures of UNHCR and other campaigns.

By embodying the figure of the refugee, that was planned for in the $1950 \mathrm{~s}$, originally reserved for white European refugees fleeing the Soviet regime, they reject the victimisation discourse that arose in the 1980s and therefore ask not mainly for financial support, but for dignity in order to become "the new Austrians", as the musician calls it.

The people described do not want to be reduced to their refugeeness and their experience of war, violence and flight, but embraced as full humans with whom to interact. They do not strive only for compassion, but cooperation. They desire to move on, forge their futures and escape only being perceived by their past. They want to leave their enforced non-temporality as refugees. By reclaiming agency and empowerment they represent a counter story to the "suffering victim" trope that dominates public discourse on refugeeness - a point of the story, which is often left out. 


\section{Quoted Literature}

BAKEWELL O. (2010), Some reflections on structure and agency in migration theory. Journal of Ethnic and Migration Studies, 36 (10), pp. 1689-1708.

Bleiker R. (2001), The aesthetic turn in international political theory. Millennium 30 (3), pp. 509-533.

De Jong G.F. \& FAwcetT J.T. (1981), Motivations for migration: an assessment and a valueexpectancy research model.

Elie J. (2014), Histories of Refugee and Forced Migration Studies. In: Fiddian-QASMiYen E., Loescher G., Long K. \& Sigona N. (eds.), The Oxford Handbook of Refugee and Forced Migration Studies, 23, pp. 22-35.

FABIAN J. (1983), Time and the Other: How Anthropology Makes its Object. Colombia University Press.

Johnson H.L. (2011), Click to Donate: visual images, constructing victims and imagining the female refugee. Third World Quarterly, 32 (6), pp. 1015-1037.

Maнmood S. (2005), Politics of piety: The Islamic revival and the feminist subject. Princeton University Press.

MalkKi L. (1995), Purity and Exile: Violence, Memory, and Hutu Cosmology among the Hutu Refugees in Tanzania. University of Chicago Press.

Nyers P. (2004), Introduction: What's left of citizenship? Citizenship studies, 8 (3), pp. 203-215.

PARTSALIS L. (08.03.2016), online under: <http://picturethislp.tumblr.com/> (accessed: $09.10 .2016)$

RAJARAm P.K. (2002), Humanitarianism and Representations of the Refugee. Journal of Refugee Studies, 15 (3), pp. 247-264.

Soguk N. (1999), States and strangers: Refugees and displacements of statecraft. (Vol. 11).

SPIVAK G.C. (1988), Can the subaltern speak? Can the subaltern speak? Reflections on the history of an idea, pp. 21-78.

TAGaris K. (2016), Greek grandmother, fisherman among Nobel Peace nominees. Available under: <http://www.reuters.com/article/us-nobel-peace-greece-idUSKCN0VA2V5> (accessed: 09.10.2016)

United Nations High Commissioner for Refugees (UNHCR) (1991), Images of Exile 1951-1991. Geneva, UNHCR.

WiNTER R.P. (1988), The year in review, in USCR, World Refugee Survey, Arlington.

ZETter R. (2007), More labels, fewer refugees: Remaking the refugee label in an era of globalization. Journal of Refugee Studies, 20 (2), pp. 172-192. 
